\title{
SPORTS MEGA-EVENTS AND THEIR WIDER SOCIAL IMPORTANCE THROUGH PUBLIC RELATIONS ACTIVITIES
}

\author{
Nenad Perić \\ Metropolitan University, College for Communications, Belgrade \\ Branko Bošković** \\ College for Sports and Health, Belgrade \\ Igor Radošević*** \\ Metropolitan University, Belgrade
}

\begin{abstract}
An $\mathrm{n}$ amazing development of sport business has been present in the past decades. This trend started in the mid-twentieth century. One of the basic reasons for this state is the marketing, media and PR conversion of major sports events into spectacles with properties of a short-term global phenomenon. Benefits of such a global expansion of sports mega-events are not purely financial, although the financial benefit is the most obvious one. The positive effect of PR of sports mega-events is generating the positive attitude of sport and sport practice. Trend of actively spending one's leisure time is derived from a general interest in sport activities today (though this is not necessarily followed by practicing sport activities). Therefore, there is an emphasized need for further development of Public Relations and Communication strategies, knowledge and understanding of the communication management of sports events. The coordinated implementation of PR activities and communication methods in sports reduces potential negative social impacts and any financial losses on the one hand, but it more commonly increases the benefits of the aforementioned elements. Analyses and research in this field are rare and therefore this paper represents initial theoretical contribution. The paper analyzes the special event-sporting spectacle as an instrument of PR communication in the broader social context.
\end{abstract}

Key Words: special event, sports event, Public Relations, mega event

\section{Introduction}

T he last decades of the previous century and the beginning of this one have brought about revolutionary changes in how organisation and management of sporting events are perceived. There is no dilemma whatsoever that sport has become large and

\footnotetext{
* Nenad Perić, PhD, Full professor

** Branko Bošković, PhD, Associate professor, branko.boskovic@vss.edu.rs

*** Igor Radošević, PhD, Assistant Professor, igor.radosevic@metropolitan.ac.rs
} 
serious business. Sport today is a place of fluctuation of enormous amounts of money and interest. In the most developed countries, sport and its accompanying elements employ a large number of people and make an important factor in the overall development of those countries. Big sporting events (mega-events) are an important element in directing sport towards an international or global society. Due to its media exposure, mega-events have not only sporting, but also economic, commercial, political, sociological and other connotations and consequences. The aim of this paper is to uncover the interdependence between sports mega-events and Public Relations, as well as the potential of different communication instruments in the organization of big sporting events, in a broader social context. The authors have also pointed out the importance and role that the targeted communication has, not only in its role of long-term sport and sporting events' profitability and success, but also in its role of developing sportsmanship and healthy lifestyle.

From a marketing point of view, every sporting event is a potential sport product that has its multiple customers. Each sporting event or competition, more or less, attracts a great public interest; it is, therefore, one of the best positioned events and has the potential for creating profit by employing marketing activities [1]. A sporting event is one of the basic pillars of sport and marketing resources of any sporting society, club, competition organizer, sportsperson or coach. The sporting event mirrors the efficacy not only of a sport practice and sports preparation, but also of other roles of a sports organization and sport in general including the efficacy of management and its role in achieving the goals of a sports organization. Sports competition is a main category of any sport activity and it is considered to be the most important role of any sportsperson or sporting event. Competition is the reason for any sporting event. The development of media and individual travel possibilities has created the basis for the accelerated development of sport and sporting events, which has attracted enormous financial resources, so we can talk about sport industry in continuous expansion [2]. Marketing and public relations play an extremely important, sometimes even inevitable, role in all of the abovementioned.

\section{Correlation between sport and public relations}

Popularity of any sport, competition, sportsperson or brand represented by media at all levels (events themselves, public relations and mass media) is becoming more widely spread. This is in good part encouraged by extreme efforts in the area of public relations [3]. In that sense, we agree with Tomic thesis that sport shall become professional and commercial exercising, slowly turning into showbusiness [4]. Communication represents the third phase in the public relations process, and comes after investigation and planning. This phase, also called execution, is publicly the most obvious part of the public relations work. When it comes to the instruments of communication, professor Kirk Hallahan at Colorado State University points out that today's communication revolution has offered a whole range of communication media and instruments to the public relations experts, and that the traditional approach according to which it is enough to gain mass media publicity is no longer valid [5].

In the 1970s and 1980s, when the International Olympic Committee allowed professional athletes to take part in the Olympic Games, sport became the professional 
competition at the global level, and the development of the sports industry has since unstoppably grown because of the great interest of viewers and the media. Also, the number of sports competitions has increased.

When organizing a special event, a resonant effect is expected with the main goal to build a certain image, in the sense of attracting attention and winning the affection of the targeted public in order to start the development of a communication chain as wide and long as possible [6]. When talking about events and experiences, there are a lot of advantages:

1) relevance: a well-picked event is seen as highly relevant, since the consumer is personally involved;

2) inclusion: considering their active nature and what happens in real time, consumers believe the events are something that makes them more included;

3 ) implicity: the events resemble to an indirect, soft sale, i.e. sale that requires no excessive convincing.

As defined by the American Association of Advertising Agencies, integrated marketing communications is the concept of marketing communication planning, which recognizes the additional value of a comprehensive plan. Such a plan evaluates the strategic role of numerous communication disciplines. Integrated marketing communications should improve the ability of a company to reach targeted customers, with a real message, at the right place at the right time; so, the most important aspect of such actions is to develop the concept of focusing communication. Due to the fact that organisations do business in the conditions of the increased level of competitiveness and setting high standards in the whole business environment, the only way to get successful results is to precisely define the public and guide narrowly specified and concrete business activities towards each of the targeted groups. Special events are one of the best ways to communicate with most social groups, and separately speaking, big sporting events are an excellent basis for the implementation of public relations.

Moreover, public relations of sports organization represent one of the most important methods of promoting the whole organisation, its products or services. Sport has many traits of a public service and in this sense it is obligated to withstand both positive and negative reactions from the public, usually presented by the means of mass-media [7].

\section{Sports mega-events and public relations}

Although the phenomenon of an event was present a long time ago, its frequent use, firstly in business purposes followed by the use in scientific and investigative purposes, as well, is linked to the industrialization period and later, modern development of human civilisation. This period is characterized by the increase in and dominance of various services with the implication that business, cultural, entertaining, sporting, recreational and other activities and ceremonies get a special spot. However, the event has always been a natural human need, although not the primary one, but one that is of great importance for a person as a social being because it represents a union of people and relationships formed by various interactions at a specific place and at the specific time, between participants, organizers, hosts and visitors, each of them with their respective general and individual goals. 
There are big differences in how an event is defined. A number of authors see events as experiences. Events consist of a large number of miscellaneous services which represent experiences. Therefore, an event can be seen as a union of individual experiences which, through synergy, offer us the level of the total experience of an event [8]. Webster's dictionary, on the other hand, defines an event as „any of the contests in a program of sports" or "any one of the parts of a sports program". The event is a unique moment in time celebrated by ceremonies and rituals in order to satisfy needs [9].

Each event influences a local and wider community. The influence may be economic, political, or promotional one, and depending on its effects it can be big or small, positive or negative one. Some events considerably change the behaviour of the environment they take place in: the percentage of criminal behaviour drops, infrastructure is developed and maintained, the sense of household behaviour in local population increases, volunteering work contributes to the success of an event and the expenses are decreased [10]. On the other hand, their effect can be diametrically opposed to the previously listed items. Sporting events are a powerful instrument of communication with the public which, like other tools, should be used only for the right reasons and with clearly determined goals; otherwise, counter effects can be produced. According to Masterman, there are „owners" and „organizers" of sporting events, as well as „depositors" which include "consumers, suppliers, partners, investors, staff and external influences" [11]. For this particular reason, organising events is of special importance in the public relations area, and, depending on the occasion, it can be an irreplaceable public relations tool.

The nature of organising small local events, medium-sized and international mega-events is the same when talking about management functions. The differences are: size, techniques, intensity, details in planning and matters of responsibility distribution [12]. A sporting event is defined as a "mega-event" when it is discontinuous, unusual, international, or, simply, big. Roberts' definition of a mega-event implies that it has an ability to transfer a promotional message to billions of people via television and other telecommunication means [13].

Mega-events are best defined as big cultural, commercial and sporting events, dramatic in character, and of mass and international importance [14]. Two central characteristics of modern mega-events are, firstly, that they have great consequence for the host, region where they are held at, or the nation in question; and secondly, that they attract big media attention. Also, it should be borne in mind that events are the fastest growing phenomenon based on business, leisure and tourism [15].

Sports mega-events have been a growing international phenomenon for a couple of last decades. This growth is a result of modern technologies for mass-communication that reach the broadest range of population. Sport, media and businesses have come together, and that changed professional sport at the turn of the 20th century; and there is also a wide range of benefits the mega-events offer to host cities, regions and countries in which they take place [16].

Roche describes mega-events as „short-term events with long-term consequences“ [17]. This description clearly points to big commercial, as well as political, social and cultural motive inspiring cities and countries to apply for the host of an event such as the Olympic Games or FIFA World Cup. Getz quantifies this definition by emphasizing the fact that the number of visitors should be higher than 1 million people, expenses should be less than 500 million dollars, and the reputation of the event itself should read: „the event you just can't miss“. 
Global sporting events today, such as the Olympic Games or World Cup, are being aggressively promoted to both companies and fans. It is estimated that approximately 3.9 billion people, for example, watched parts of the Olympic Games in Athens in 2004 on TV. 35,000 hours were dedicated to the media, which is a $27 \%$ increase since the summer Olympic Games held in Sydney in 2000 (Hallahan, 2014). Sports mega-events such as the Olympic Games, the FIFA World Cup and the UEFA Champions League have a significant influence on the host's region, and the possibilities for utilizing public relations are enormous. The Beijing Olympic Games in 2008 registered an increase in ratings compared to the Olympic Games held in Athens - according to AGB Nielsen there were 4.7 billion viewers [18].

These events are very popular and attract large audience and TV viewers. For example, in 2004 an average of 150 million viewers watched the UEFA Champions League in Portugal per match, a $157 \%$ increase in comparison to the European Football Championship held in Belgium and the Netherlands in 2000. Approximately 500,000 spectators travelled to Portugal to watch the championship [19]. The opening ceremony of the London Olympic Games was watched by 900 million people all over the world, which set the new ratings record for a sporting event [20]. Any serious sporting event represents the affirmation of the hosting venue and simultaneously the promotion of sponsors and sports equipment, advertising, etc. Potential positive results of sports mega-events include commercial growth, such as increase in revenue, better possibilities for employment, tourism growth, and especially the improvement of the host country's image [21]. The improvement of the host country's image can be the greatest benefit of organizing sport mega-events. Economic growth, infrastructure improvement and image promotion are the holy trinity of mega-event benefits [22]. In order to exploit all the listed possibilities to the fullest extent, the use of public relations needs to be intensive and adequate.

Russia is the country that has best used the organization of sports mega events through public relations. The state has realized that sport should be used as a method for raising Russia, both locally and globally. Russian internal interests are investment in the sports industry, through investing in sports infrastructure, organizing mega events, raising the quality of competitions in the most popular sports such as football, basketball and hockey, so that Russian sport can match the top sports leagues in Europe and the United States. Also, by investing in sport, Russia invests in the development of the country in the long run. Therefore, a plan has been made for Russia to bid for the host of the world's largest sports diving. The budget for organizing the Winter Olympics in Sochi 2014 amounted to over $\$ 50$ billion. Security costs amounted to three billion dollars. Approximately 50,000 security personnel were deployed in Sochi beside 3,000 athletes. Security services installed 1,400 cameras that were used for surveillance, the sky above Sochi was protected by combat aircraft, drones, while warships and submarines were deployed on the sea [23].

Also, in the case of the organization of the World Cup football events in Russia in 2018, we can see the social impact through public relations not only for the Russian citizens, but also for the global level. The Olympics gave public relations outstanding chance for global promotion of Russia, its cities, history, tradition, customs, language and culture. Russia has used the organization of the World Football Championship to renovate and build new modern stadiums in 11 cities. The money invested will return multiple times. Russia inherited 
the wasted infrastructure from the time of the Soviet Union, and the investment and renovation and construction of new sports facilities was absolutely necessary. Russia has, from the diplomatic point of view, used the organization of the Olympic Games and the World Cup to spread its social influence, even though it is under the US and EU sanctions because the world leaders have come to support their national teams, as well as about 1.5 million foreigners who have come to Russia during the event (according to various estimates). Overall, over 1.8 million tickets were sold for the matches, according to the official website of the FIFA World Cup. It's hard to imagine such number of visits to Russia if there was no organization of the biggest sporting events.

\section{The effects of sports mega-events, their communication and public relations}

The image of sports mega-events' host is one of the final outcomes of the activities guided towards creating and establishing appropriate communication connections with individuals and targeted public. Developing a relationship with the public is of integral importance in this sense. Event communication is a management tool by which all internal and external communication is coordinated effectively and efficiently, to the highest possible extent, in order to create a favourable base for the organizer-targeted public group relationship, so as to achieve more successful business results. Corporate reputation is formed based on the experience related to a particular event. The perception of all of the groups included in planning, conducting and evaluating an event, is of special importance when it comes to winning the approval and love of people towards events, organizers, sponsors, etc. Prior to discussing the image, it is necessary to create a strong identity. This is the reason why most of sports mega-events have so far been held in the developed countries. However, a number of transitioning countries, including Middle Europe and sub-Saharan Africa, are trying to have the right to organize mega-events such as the World Cup or the Olympic Games granted to them by international sport organizations through lobbying [24]. The role of public relations in such activities is of crucial importance. The public is more or less aware of the fact that candidacy for organizing big events (not just sport events, but events in general) is often awarded through lobbying, which is one of public relations instruments.

The main benefit of a mega-event is national and international exposure. Sport fans increase the tourist income for that area during their visit. Corporate sector visitors may move their production, company or factory to host cities. Adidas opened its 4,800 stores in China prior to the Beijing Games in 2008, seeking to promote its brand that sponsored the Olympic Games in order to position itself in the market of 1.3 billion [25]. TV audience may decide to visit the host city at some point in the future due to what they have seen during the airing of a mega-event. The rights to live TV coverage of a mega-event are a good income source, sometimes bigger than any other source. The sale of TV rights makes up $47 \%$ of the budget of the International Olympic Committee. Finally, hosting a big event may improve the image of a cityto such an extent that it can become a tourist destination. Still, there are examples to the contrary [26]. An example is the riot following the NBA championship in Detroit in the nineties: the image of the city was that of cars 
and buildings in flames, and not of good atmosphere related to the NBA championship. Similarly, the international reputation of Munich and Atlanta was weakened by terrorist attacks that happened during the Olympic Games in those cities [27]. It is due to these cases that public relations should have detailed crisis plans and exercised scenarios.

\section{Wider social influence of sports mega-events}

Sport has a key role in every society through its contributions to social cohesion, by overcoming prejudice, increasing positive impacts on public opinion and spreading ethical and general principles. The Sports Development Strategy in the Republic of Serbia 2014-2018 states that citizens may be participants of sport activities, but may also take part in them as passive onlookers, that is, as spectators or sport fans [28].

The development of new technologies contributes to better and faster functioning of people, but at the same time reduces physical activity and thus contributes to the worse health housing with a special emphasis on children. The main problem of most countries is the health of the nation that is seriously disturbed because the health problem is mostly related to children with more and more health problems in the form of obesity, spine curves, flat soles, impaired vision and improper holding, and the cause is the lack of physical activity.

Despite the importance of a physical activity, the percentage of people regularly doing a physical activity in our country is still low. One of the first preconditions for finding a solution for increasing citizens' mobility to engage in physical activity is discovering the cause behind their passiveness in relation to physical exercise. When comparing EUROBAR data with CESID research data, it can be seen that the lack of time is the main reason for low participation in sport activities. The results referring to the lack of time for engaging in physical activity are very similar in the European Union and Serbia. In fact, $45 \%$ of respondents in the EU state this as a primary reason, while in the Republic of Serbia this number is smaller and at a level of about $40 \% .5 \%$ of respondents in the European Union state that engaging in physical activities is too expensive, while in the Republic of Serbia $2 \%$ claim they lack the finances for doing so. The unavoidable question is: What is the problem? The problem is promoting sport and the healthy lifestyle through sport participation. The authors are of the opinion that good public relations concerning sports mega-events are the key factor in the process of enlightening wider social communities. After the London Olympic Games, $28 \%$ of the British said the Games increased their participation in sport activities, and $85 \%$ confirmed the Olympic Games had achieved their goal - to inspire younger generations to do sports [29].

In Serbia, for example, every May, when the finals of the NBA League begin, all basketballs courts are taken up, which is primarily due to media coverage. The same applies with the European and World Football Championships. Children are then further motivated to engage in sport and join sports clubs.

The power of sport is enormous, as is that of sports mega-events. Nelson Mandela once said: "Sport has the power to change the world. It has the power to inspire. It has the power to unite people in a way that little else does. Sport can awaken hope where there was previously only despair. Sport speaks to people in a language they can understand." It is upon public relations to use this for higher and greater social goals. 


\section{Conclusion}

Like any special event, sporting events, especially sports mega-events, can be the reason behind a serious communication activity, prepared and analysed through public relations. This paper analyses the relationship and effects that communication and public relations have with/on sporting events, as well as the basic possibilities of applying them to sports mega-events. We have also pointed out the impact and power of sporting megaloms that can skip political barriers and connect people to the nations. The data presented here referring to the biggest mega-events such as the Olympic Games and the FIFA World Cup are merely indicators of possible wider impact on all public segments, that is, of enormous sports mega-events' power in a wider social context. It would be interesting to analyse in more detail specific events which can be seen as sports mega-events in our region in terms of organizing, planning and executing public relations activities. Special events are one of the best ways to communicate with most social groups, and separately speaking, big sporting events are an excellent basis for implementation of public relations. Social aspects and wider social implications are very important, but were not discussed in depth here. Furthermore, actively spending leisure time is one of the highly important segments when it comes to promoting sports and sport communication practitioners have to bear this in mind. The purpose of organizing mega-events is not only to make profits, but also to promote sports activities and a healthy lifestyle. Also, such opportunities are used for construction of new and renovation of old sports infrastructure, which afterwards will be used by local sports clubs. Finally, this area deserves attention and, considering the given trend and rate the sport world is being developed at, it shall only expand more in the future.

\section{References}

[1] Tomić, M. (2007): Sportski menadžment, Data Status, Beograd.

[2] Koprivica, M. (2008): Menadžment događaja, USEE, Novi Sad.

[3] Vilkoks, D., Kameron, G., Olt, F., Ejdži, V. (2006): Odnosi s javnošću - strategije i taktike, Ekonomski fakultet, Beograd.

[4] Tomić, M., (2007): Sportski menadžment, Data Status, Beograd.

[5] Hallahan, K. (2014): Organizational goals and behavioral objectives in strategic communication. In Derina Holtzhausen \& Ansgar Zerfass (Eds.), Handbook of strategic communication, New York: Routledge, 244-265.

[6] Filipović, V., Kostić-Stanković, M. (2008): Odnosi s javnošću, FON, Beograd

[7] Tomić, M., (2007): Sportski menadžment, Data Status, Beograd.

[8] Koprivica, M. (2008): Menadžment događaja, USEE, Novi Sad.

[9] Goldblatt, J. (2002): CSEP Special Events, 21st century Global Event Management, JohnWiley \& Sons, Inc., New York

[10] Skambler, G. (2007): Sport i društvo, Clio, Beograd.

[11] Masterman, G. (2008): Strateški menadžment sportskih događaja, Clio, Beograd.

[12] Shone, A., Parry, B. (2010): Successful Event Management, A Practical Handbook, III edition, Cengage Learning, Hampshire.

[13] Roberts, K. (2004): The Leisure Industries, Palgrave, London. 
[14] Roche, M., 2000. Mega-events and modernity, Routledge, London.

[15] Getz, D. (1997): Event Management and Event Tourism. New York: Cognizant Communications.

[16] Horne, J., Manzenreiter, W. (2006): An introduction to the sociology of sports megaevents, The Sociological Review, 54:1-2, 9.

[17] Roche, M., 2000. Mega-events and modernity, Routledge, London.

[18] Source: http://www.nielsen.com/us/en/insights/news/2008/beijing-olympics-draw-largestever-global-tv-audience.html

[19] Source: www.olympic.org/uk

[20] Source: http://sites.nielsen.com/london2012/fast-facts/

[21] Jones, C. (2001): Mega-events and Host-region Impacts: Determining the True Worth of the 1999 Rugby World Cup, International Journal of Tourism Research, 3, 241-251.

[22] Matos, P. (2006): Hosting mega sports events - a brief assessment of their multidimensional impacts, The Copenhagen Conference on the Economic and Social Impact of Hosting Mega Sport Events, 01.09.2006.

[23] Source: https://en.wikipedia.org/wiki/2014_Winter_Olympics.

[24] Baade, R., Matheson, V. (2003): Mega-Sporting Events in Developing Countries, http://web.williams.edu/Economics/wp/mathesonprosperity.pdf.

[25] Source: https://www.adidas-group.com/en/media/news-archive/press-releases/2008/adidas-groupexcels-worldwide-and-china-brand-adidas-takes-marke/

[26] Source: https://www.olympic.org/ioc-financing-revenue-sources-distribution

[27] Matheson, V. (2006): Mega-Events: The effect of the world's biggest sporting events on local, regional, and national economies, Work Material No. 610, College of the Holy Cross, Department of Economics.

[28] Strategija razvoja sporta u Republici Srbiji za period 2014-2018. godine (Sl. glasnik RS br. 1/2015)

[29] Source: http://sites.nielsen.com/london2012/fast-facts/. 